Original Article

\title{
ASSESSMENT OF INTRAOCULAR PRESSURE FOLLOWING THE INTRAVITREAL INJECTION OF ANTI-VEGF
}

\author{
CHAKAR TAJWIDI1,2, SHIASTA TABASSUM1,2, RAHMAM GUL ${ }^{2,3 *}$
}

${ }^{1}$ Helper Eye Hospital Quetta, Baluchistan, 2Department of Health Government of Baluchistan, Pakistan, ${ }^{3}$ Institute of Public Health Quetta Email: gul.dotani@yahoo.com

Received: 04 May 2021, Revised and Accepted: 02 Jul 2021

\begin{abstract}
Objective: The objective of the study is to assess the frequency of raised IOP after intravitreal injection of Anti VEGF by using an applanation tonometer.
\end{abstract}

Methods: Each patients who fulfil the presence criteria were nominated by the researcher through the outpatient department (OPD) of ophthalmology, Jinnah Post Graduate Medical Center. Performa was filled. Aim and process of study was explained to all patients. Conversant consent was reserved. Model ocular inspection, including IOP was done.

By using either a 30-or 32-gauge needle, $1.25 \mathrm{ml}$ bevacizumab (Avastin) were administered by the researcher under the direct supervision of consultant. Patients were consistently sterilely prepped, that was comprised incerted of topical antibiotic and anesthetic drops, supplement of a lid speculum. Later pointing the injection place on the sclera with a caliper calculating 3.0 to $3.5 \mathrm{~mm}$ after limbus, conjunctiva was expatriate somewhat through a sterile cotton-tipped applicator immediately earlier ingoing the eye by a needle. Later injection, place was occluded provisionally it was amended through a sterile cotton-tipped applicator while the needle remained inhibited from the eye. Since the needle was inhibited, a drop of anesthetic was employed on the cornea and IOP was measured. Then next IOP interpretation was measured later 1 day of intravitreal Avastin.

All pressures were measured using the applantation tonometry. IOPs were measured earlier intravitreal Avastin "baseline IOP" and instantly following injection "T0" and 1day next injection.

Results: 235 Patients exactly nominated for the research study. Intravitreal Injection, Bevacizumab was applied in 235 Eyes of overstated 235 patients. Elsewhere of the 235 patients, 133 males and 102 females, Their ages ranged from 30-70 y (mean 52.02 y. The most shared sign intravitreal with bevacizumab, diabetic retinopathy observed in 114 (48.5\%) patients, indicated by exudative ARMD in 70 (29.7\%) patients, BRVO in 12 (5\%) patients, Myopic CNV23(9.7) with CRVO observed in $11(4.6 \%)$ patients, Eale's sickness in 2(0.85\%) patients even as Idiopathic CNV was observed in only $3(1 \%)$ patient. Of the 235 patients, $118(50.2 \%)$ patients with right eye suffered, 117(49.7\%) patients with left eye suffered. After $24 \mathrm{~h}$ of intravitreal Bevacizumab Raised IOP was observed in only 3 (1.28) patient and 232(98.2) patient IOP was in the normal range. According to our study, the result of stratification with respect to age, side of the eye and gender is not significant as p-value for age (0.838), gender (0.723) and side of the eye (0.556), respectively.

Conclusion: In our study, frequency of raised IOP after anti VEGF were found 3(1.28) patient out of 232 (98.2). Anti-VEGF treatment is the foundation for the management of numerous retinal illnesses. Notwithstanding its capable effectiveness in uncertain the sickness and refining, vision for the patients, intravitreal injection of anti-VEGF products may be related with overwhelming problems. To diminish the risk cautious care to the injection method and suitable post-injection observing are essential.

Keywords: Anti-VEGF, Intraocular pressure, Applanation tonometer

(c) 2021 The Authors. Published by Innovare Academic Sciences Pvt Ltd. This is an open access article under the CC BY license (https://creativecommons.org/licenses/by/4.0/) DOI: https://dx.doi.org/10.22159/ijcpr.2021v13i5.1885 Journal homepage: https://innovareacademics.in/journals/index.php/ijcpr

\section{INTRODUCTION}

The most important reason of blindness in progressive countries are neovascularization of the choroidal and retinal tissue [1]. Vascular endothelial enlargement issue has been recognized since a main angiogenic inducement in diversity with retinal and choroidal neovascularization [2]. Vascular Endothelial Growth Factor is homodimeric glycoprotein and is a enlargement issue exact for endothelial cells [3]. It is not only indorses the enlargement and continuation of vascular endothelial cells, other than in addition causes conformational changes of tense junctions of retinal vascular endothelial cells primary to increased vascular penetrability [4].

Bevacizumab (Avastin) is a humanized monoclonal antibody which is known to stops vascular endothelial growth factor A "VEGF-A" It is a chemical signal that rouses the enlargement of novel blood vessels "angiogenesis". Today intravitreal Bevacizumab is used to heal the subsequent disorders:

1). CNV caused by pathological myopia [5]

2). Iris neovascularization with Proliferative diabetic retinopathy [6].

3). Idiopathic CNV [7].
4). Retinal vein occlusion [8].

5). CNV caused by Age related Macular Degeneration [9].

6). Proliferative diabetic retinopathy [10].

The inducing of extra solution into the hollow vitreous space by intravitreal treatment must be predictable to cause an instant increase in the intraocular pressure "IOP". This fleeting, temporary IOP promotion following intravitreal anti-VEGF treatment has been sound defined [11-14].

As per Centre for Medicare and Medicaid Services, intravitreal injections could be the speedy rising ophthalmic technique in 2006 . as a result, it is significant to examine behavior to guarantee patient security whereas refining in general patient knowledge and effectiveness of patient flow in the place of work with these theraphies. According to the research done by kampougeris G, Spyropoulos D prevalence of raised IOP is $2.5 \%$ after intravitreal injection of Anti VEGF.

The rationale of this study is to evaluate raised IOP after intravitreal injection of $1.25 \mathrm{mg}$ of "Avastin". Although many researches have done on intravitreal Avastin but its effect on IOP is not available. The 
study will generate data, which will facilitate the healthcare system by assessing temporary tendencies and the essential to screen intraocular pressure "IOP" changes directly after intravitreal injections of Anti VEGF to safeguard patient safety.

\section{MATERIALS AND METHODS}

\section{Subjects and methods}

This cross-section study was conducted at Jinnah Post Graduate Medical center. All patients who fulfill the inclusion criteria were selected by "the outpatient department "OPD" of ophthalmology, Jinnah Post Graduate Medical Center. Performa was filled. Purpose and technique of the study were explained to all patients. Conversant consent was received. Baseline ocular examination, including IOP was done.

By using either a 30-or 32-gauge needle, $1.25 \mathrm{ml}$ bevacizumab (Avastin) were administered by the researcher under the direct supervision of a consultant. Patients were evenly sterilely prepped, that incorporated insertion of topical antibiotic and anesthetic drops, installation of a lid speculum. Later design, the injection site on the sclera through a calliper measuring $3.0-3.5 \mathrm{~mm}$ after the limbus, the conjunctiva was expatriate somewhat among a sterile cotton-tipped applicator immediately earlier toward the inside the eye with a needle. Later injection, spot was occluded provisionally and was rubbed among a sterile cotton-tipped applicator while the needle was removed since the eye. By way of the needle was removed, a drop of anesthetic was located on the cornea and IOP was observed. Then next, IOP appraisal was observed after 1 day of intravitreal Avastin.
Entirely pressures were observed using the applanation tonometr. IOPs were observed before intravitreal Avastin (baseline IOP) and instantly after injection (T0) and 1day after injection.

\section{Data anylasis}

Statistical analysis were done utilizing IBM SPSS software version 20.0. Incidences and fractions, calculated for definite variables similar to gender, side of the eye and raised IOP. Standard deviation and mean of quantitative variables similar to age were calculated. Stratification with respect to age, side of the eye and gender was completed. Post-stratification chi-square test was practical. $\mathrm{P}<0.05$, observed as significant.

\section{RESULTS}

235 Patients completed this study. Intravitreal Injection of Bevacizumab was given in 235 Eyes of above mentioned 235 Patients. Out of the 235 patients, 133 were males and 102 were females (table 4 and fig. 32). Their ages ranged from 30 to $70 \mathrm{y}$ (mean $52.02 \mathrm{y}$ ). The most shared sign of intravitreal bevacizumab would be diabetic retinopathy found in $114(48.5 \%)$ patients, followed by exudative ARMD in 70 (29.7\%) patients, BRVO in $12(5 \%)$ patients, Myopic CNV23(9.7) and CRVO found in $11(4.6 \%)$ patients, Eale's disease in $2(0.85 \%)$ patients while Idiopathic CNV was found in only $3(1 \%)$ patient. Table 1 . Of the 235 patients, $118(50.2 \%)$ patients with right eye suffered, 117(49.7\%) patients with the left eye suffered. After $24 \mathrm{~h}$ of intravitreal Bevacizumab Raised IOP was seen in only $3(1.28)$ patients and 232(98.2) patient IOP was in normal range. According to our study, the result of stratification with respect to age, side of the eye and gender is not significant as the pvalue for age (0.838), gender $(0.723)$ and side of the eye $(0.556)$, respectively (table 6, 7, 8).

Table 1: Gender frequency

\begin{tabular}{lll}
\hline Gender & Frequency & Percent \\
\hline Male & 133 & 56.6 \\
Female & 102 & 43.4 \\
Total & 235 & $10 \mathrm{~s} 0$ \\
\hline
\end{tabular}

Table 2: Descriptive statistics of age profile

\begin{tabular}{llllll}
\hline $\mathbf{n}$ & Minimum & Maximum & Mean & Std. Deviation & Median \\
\hline 235 & 30 & 70 & 52.2766 & 9.59278 & 52.2766 \\
\hline
\end{tabular}

Table 3: Diagnosis

\begin{tabular}{ll}
\hline & No. of patients n (\%) \\
\hline DR & $114[48.5]$ \\
ARMD & $70[29.7]$ \\
Myopic CNV & $23[9.7]$ \\
CRVO & $11[4.6]$ \\
BRVO & $12[5]$ \\
Idiopathic CNV & $3[1.2]$ \\
\hline
\end{tabular}

DR: diabetic retinopathy, ARMD: age-related macular degenerations, Myopic CNV: myopic choroidal neovascularisation, CRVO: central retinal view occlusion, BRVO: branch retinal view occlusion, Eale's Disease, Idiopathic CNV: idiopathic choroidal neovascularization

Table 4: Side of the eye

\begin{tabular}{lll}
\hline Side of the eye & Frequency & Percent \\
\hline Right eye & 118 & 50.21 \\
Left eye & 117 & 49.79 \\
Total & 235 & 100 \\
\hline
\end{tabular}

Table 5: Raised IOP after 24h

\begin{tabular}{lll}
\hline Raised IOP after $\mathbf{2 4} \mathbf{h}$ & Frequency & Percent \\
\hline YES & 3 & 1.28 \\
NO & 232 & 98.72 \\
Total & 235 & 100.0 \\
\hline
\end{tabular}


Table 6: Stratification by age

\begin{tabular}{lllllll}
\hline Age group & $\mathbf{3 0 - 4 0}$ & $\mathbf{4 1 - 5 0}$ & $\mathbf{5 1 - 6 0}$ & $\mathbf{6 1 - 7 0}$ & Total \\
\hline YES & 0 & 1 & 1 & 1 & 3 \\
NO & 35 & 53 & 95 & 96 & 49 & 232 \\
Total & 35 & 54 & 96 & 50 & 235 \\
\hline
\end{tabular}

Table 7: Stratification by gender

\begin{tabular}{llll}
\hline & Raised IOP after 24 h & & Total \\
\hline Male & NO & YES & p-value \\
Female & 131 & 2 & 133 \\
Total & 101 & 1 & 102 \\
\end{tabular}

Table 8: Stratification by side of eye

\begin{tabular}{lllll}
\hline & Raised IOP after 24 h & & Total & \\
\hline & NO & YES & p-value & \\
\hline Right eye & 117 & 1 & 118 & \\
Left eye & 115 & 2 & 117 & 0.556 \\
Total & 232 & 3 & 235 & \\
\hline
\end{tabular}

\section{DISCUSSION}

Ischemic conditions of eye identical central retinal vein occlusion and diabetic or hypertensive retinopathy reasons microangiopathies at tissue stage. The subsequent hypoxia leads to the issue of vascular endothelial growth factor (VEGF) 1. VEGF has double-dealings, one it reasons neovessels development, other it rises vascular penetrability, which leads to retinal edema [15].

The approach of action of Bevacizumab is to constrain the upregulation of VEGF. This in turn, will opposite the phenomena of neovascularization and edema creation [16]. Additional utilization of intravitreal Bevacizumab are retinopathy of prematurity "ROP", pseudophakic, macular edema, serious central chorioretinopathy "CSCR" and radiation retinopathy [17].

Bevacizumab has been utilized on an "off-label" foundation since the fall of 2005. While it is of abundant lesser cost than either Lucentis and Macugen "FDA approved anti-VEGF", it is utilized as the first-line theraphy in most macular degeneration patients. While no work has been conducted elsewhere before on this subject in our local system, this research study would be significant in resolution-making concerning the safety of intravitreal bevacizumab in choroidal and retinal neovascular illnesses. The most shared signs of Bevacizumab in one paper by Lihteh Wu et al. were diabetic retinopathy and $\mathrm{CNV}$ of several etiologies.

The main suggestions in our research study were diabetic retinopathy (48.5\%) followed by CNV of a variety of etiologies as well.

The manner of intravitreal anti-VEGF therapy donates to ocular hypertension is unidentified, but numerous possible mechanisms are thinkable. The drugs may have a direct pharmacologic effect on aqueous outflow via the trabecular meshwork, uveoscleral pathway, or Schlemmcanal. Reports have diverse as to whether ranibizumab or bevacizumab is toxic to anterior section cells at pharmacological doses $[18,19]$. The recurrent transient IOP rise connected to the volume of drug presented could also change aqueous outflow pathways. Chronic inflammation or trabeculitis related to recurrent intravitreal injections could theoretically donate to sustained IOP elevation [20].

Mechanical obstacle to seeping away, either by the anti-VEGF mediator or byproducts, pharmacologic formulations or storage, might be concerned. Kahook et al. [21]. Originate variable stages of highmolecular-weight protein aggregates when associating various samples of formulated preparations of bevacizumab and hypothesized that this large specific substance could lead to raised IOP by hindering aqueous outflow.
In our present study, there were just 3 cases of elevated IOP, which reappearance to usual with glaucoma medicine, thus requiring checking IOP afterward injection as protection.

A total of 253 Patients, designated for this research study. Intravitreal Injection of Bevacizumab was introduced in 253 Eyes of the above-stated Patients. Out of the 253 Patients, 133were Males and 102 were Females. Their ages ranged from 30 to $70 \mathrm{y}$ (mean $52.02 \mathrm{y}$ ). The highest numbers of patients were in their $5^{\text {th }}$ decade. While the study was conducted in a government eye hospital, bigger numbers of our patients belonging from a poor monetary background, reasonably smaller concentration towards health care problems and observance towards pursue ups.

\section{CONCLUSION}

In our study, frequency of raised IOP after anti-VEGF were found $3(1.28)$ patient out of 232(98.2). Anti-VEGF treatment is the mainstay for the management of numerous retinal problems. Notwithstanding its promising efficacy in hesitant the disease and refining the vision for the patients, intravitreal injection of anti-VEGF agents may be related with overwhelming problems. To diminish the risk, wary care to the injection system and suitable post-injection monitoring are crucial

\section{ACKNOWLEDGEMENT}

We are thankful to the Medical superintendent, Jinnah Post Graduate Medical center, Karachi and Health Department, Government of Balochistan for their timely support to outright this research.

\section{FUNDING}

None

\section{AUTHORS CONTRIBUTIONS}

All the authors have contributed equally.

\section{CONFLICT OF INTERESTS}

We have no conflict of interest

\section{REFERENCES}

1. Marano RJ, Rakoczy PE. Treatments for choroidal and retinal neovascularization: a focus on oligonucleotide therapy and delivery for the regulation of gene function. Clin Exp Ophthalmol. 2005;33(1):81-9. doi: 10.1111/j.14429071.2005.00952.x, PMID 15670087. 
2. Adamis AP, Shima DT. The role of vascular endothelial growth factor in ocular health and disease. Retina. 2005;25(2):111-8. doi: 10.1097/00006982-200502000-00001, PMID 15689799.

3. Ferrara N, Gerber HP, LeCouter J. The biology of VEGF and its receptors. Nat Med. 2003;9(6):669-76. doi: 10.1038/nm0603669, PMID 12778165

4. Otani A, Takagi H, Oh H, Koyama S, Ogura Y, Matumura M, Honda Y. Vascular endothelial growth factor family and receptor expression in human choroidal neovascular membranes. Microvasc Res. 2002;64(1):162-9. doi: 10.1006/mvre.2002.2407, PMID 12074642.

5. Rosenfeld PJ, Moshfeghi AA, Puliafito CA. Optical coherence tomography findings after intravitreal injection of bevacizumab (Avastin) for neovascular age-related macular degeneration. Ophthalmic Surg Lasers Imaging. 2005;36(4):331-35. doi: 10.3928/1542-8877-20050701-14, PMID 16156152.

6. Iturralde D, Spaide RF, Meyerle CB, Klancnik JM, Yannuzzi LA, Fisher YL, Sorenson J, Slakter JS, Freund KB, Cooney M, Fine HF. Intravitreal bevacizumab (Avastin) treatment of macular edema in central retinal vein occlusion: a short-term study. Retina. 2006;26(3):279-84. doi: 10.1097/00006982$200603000-00005$, PMID 16508427.

7. Avery RL, Pearlman J, Pieramici DJ, Rabena MD, Castellarin AA, Nasir MA, Giust MJ, Wendel R, Patel A. Intravitreal bevacizumab(Avastin) in the treatment of proliferative diabetic retinopathy. Ophthalmology. 2006;113(10):1695.e1-15. doi: 10.1016/j.ophtha.2006.05.064, PMID 17011951.

8. Oshima Y, Sakaguchi H, Gomi F, Tano Y. Regression of iris neovascularization after intravitreal injection of bevacizumab in patients with proliferative diabetic retinopathy. Am J Ophthalmol. 2006;142(1):155-8. doi: 10.1016/ j.ajo.2006.02.015, PMID 16815267.

9. Sakaguchi H, Ikuno Y, Gomi F, Kamei M, Sawa M, Tsujikawa M, Oshima Y, Kusaka S, Tano Y. Intravitreal injection of bevacizumab for choroidal neovascularisation associated with pathological myopia. Br J Ophthalmol. 2007;91(2):161-65. doi: 10.1136/bjo.2006.099887, PMID 16914470.

10. Gomi F, Nishida K, Oshima Y, Sakaguchi H, Sawa M, Tsujikawa $M$, Tano Y. Intravitreal bevacizumab for idiopathic choroidal neovascularization after the previous injection with posterior subtenon triamcinolone. Am J Ophthalmol. 2007;143(3):50710. doi: 10.1016/j.ajo.2006.10.050, PMID 17317397.

11. Falkenstein IA, Cheng L, Freeman WR. Changes of intraocular pressure after intravitreal injection of bevacizumab (avastin). Retina. 2007;27(8):1044-47. doi: 10.1097/ IAE.0b013e3180592ba6, PMID 18040242.
12. Gismondi M, Salati C, Salvetat ML, Zeppieri M, Brusini P. Shortterm effect of intravitreal injection of ranibizumab (Lucentis) on intraocular pressure. J Glaucoma. 2009;18(9):658-61. doi: 10.1097/IJG.0b013e31819c4893, PMID 20010243.

13. Sharei V, Höhn F, Köhler T, Hattenbach LO, Mirshahi A. Course of intraocular pressure after intravitreal injection of $0.05 \mathrm{~mL}$ ranibizumab (Lucentis). Eur J Ophthalmol. 2010;20(1):174-79. doi: 10.1177/112067211002000124, PMID 19927267.

14. Kim JE, Mantravadi AV, Hur EY, Covert DJ. Short-term intraocular pressure changes immediately after intravitreal injections of anti-vascular endothelial growth factor agents. Am Ophthalmol. 2008;146(6):930-4.e1. doi: 10.1016/j.ajo.2008.07.007, PMID 18775528.

15. Hollands H, Wong J, Bruen R, Campbell RJ, Sharma S, Gale J. Short-term intraocular pressure changes after intravitreal injection of bevacizumab. Can J Ophthalmol. 2007;42(6):807 11. doi: 10.3129/i07-172, PMID 18026202.

16. Pe'er J, Folberg R, Itin A, Gnessin H, Hemo I, Keshet E. Vascular endothelial growth factor upregulation in human central retinal vein occlusion. Ophthalmology. 1998 Mar;105(3):412-6. doi: 10.1016/S0161-6420(98)93020-2, PMID 9499769.

17. Marshall J. The role of bevacizumab as first-line therapy for colon cancer. Semin Oncol. 2005 Dec;32(6):Suppl 9:S43-7. doi: 10.1053/j.seminoncol.2005.06.003, PMID 16399431.

18. Arevalo JF, Garcia-Amaris RA, Roca JA, Sanchez JG, Wu L, Berrocal MH, Maia M, Pan-American Collaborative Retina Study Group. Primary intravitreal bevacizumab for the management of pseudophakic cystoid macular edema: pilot study of the Pan American Collaborative retina Study Group. J Cataract Refract $\begin{array}{llll}\text { Surg. } 2007 & \text { Dec;33(12):2098-105. doi: }\end{array}$ 10.1016/j.jcrs.2007.07.046, PMID 18053911.

19. Honda S, Hirabayashi H, Tsukahara Y, Negi A. Acute contraction of the proliferative membrane after intravitreal injection of bevacizumab for advanced retinopathy of prematurity. Graefes Arch Clin Exp Ophthalmol. 2008 Mar 5 [Epub ahead of print];246(7):1061-3. doi: 10.1007/s00417-008-0786-7, PMID 18320201.

20. Finger PT. Radiation retinopathy is treatable with anti-vascular endothelial growth factor bevacizumab (Avastin). Int J Radiat Oncol Biol Phys. 2008 Mar 15;70(4):974-7. doi: 10.1016/j.ijrobp.2007.11.045, PMID 18313522.

21. Kahook MY, Ammar DA. In vitro effects of antivascular endothelial growth factors on cultured human trabecular meshwork cells. J Glaucoma. 2010;19(7):437-41. doi: 10.1097/IJG.0b013e3181ca74de, PMID 20164801. 